Volume: 7

Issue: 2

Month: March

Year: 2019

ISSN: 2319-961X

Received: 5.3.2019

Accepted: 10.3.2019

Published: 15.3.2019

Citation:

Naagarajan, R., and K.

Jayavasuki. "Enrolment

of Health Insurance by

Cardiovascular Disease

Affected Informal Industrial

Workers in Coimbatore."

Shanlax International Journal of Economics, vol. 7, no. 2, 2019, pp. 42-51.

DOI:

https://doi.org/10.34293/ economics.v7i2.313

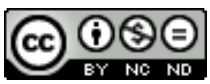

This work is licensed under a Creative Commons Attribution-NonCommercialNoDerivatives 4.0 International License

\section{Enrolment of Health Insurance by Cardiovascular Disease Affected Informal Industrial Workers in Coimbatore}

\author{
R.Naagarajan
}

Associate Professor and Head, Department of Economics

PSG College of Arts and Science, Coimbatore, Tamil Nadu, India

\section{K.Jayavasuki}

Ph.D. Research Scholar, Department of Economics

PSG College of Arts and Science, Coimbatore, Tamil Nadu, India

\begin{abstract}
Health care costs have risen drastically over few years, and any medical treatment can make a dent on individual's savings but with the help of these special health insurance plans, an individual can give extra cushion to them and can come out good from these problems. Insurance may be described as a social device to reduce or eliminate the risk of life and property. Under the plan of insurance, a large number of people associate themselves by sharing risk, attached to an individual insurance plan that exclusively covers healthcare costs and is called Health Insurance. One possible solution to the above said problem was to reduce the financial barrier through health insurance. Unfortunately, currently only about 10 percent of the population protected under any health insurance coverage. The most are for employees in the formal (Ellis et al. 2000). The informal workers were unprotected and had to depend on those above poorly financed public sector or the expensive private sector to take care of its needs. The government is keen to increase the insurance coverage and has even introduced special health insurance packages for the poor (Times of India, 2003). Health insurance schemes are one way of guaranteeing access to health care services. Under such schemes ideally, people should apply for membership and be making monthly contributions so that in the event of any sickness; the health insurer will be able to meet the cost of medical care. Health insurance plays important role in healthcare service provision. It should again be noted that the health insurance market depends on policy interventions to balance supply side and demand side forces. Demand-side forces would naturally involve health insurance participation, and for credible policy interventions it may be important that those factors affecting participation be established (Mhere, 2013). Health insurance is the fast emerging as an important mechanism to finance the health care needs of the people. The need for an insurance system that works on the basic principle of pooling risks of unexpected costs of persons falling ill and needing hospitalization by charging a premium from a wider population base of the community (Bhatia and John, 2000). Work-related health problems result in an economic loss of four to six percent of gross domestic product for most countries. About 70 percent of workers does not have any insurance to compensate them in case of occupational disease and injuries.
\end{abstract}

Keywords: Health, informal, insurance, demand, hospitalization, insurance schemes

\section{Introduction}

Health insurance means the insurance that covers the cost of medical and surgical expenses of an individual and important means to finance the healthcare needs of the people. Health insurance has emerged as the fastest growing insurance sectors in India, yet there are people who are still unaware of the health insurance policies that can be provided to the workers (Sachin and Kumar, 2014). Health insurance has become an important constituent of the insurance portfolio of an individual. 
All health insurance companies offer various types of health insurance plans to cater to every health insurance needs of an individual. Companies have started offering specialized health insurance policies as critical illness insurance, insurance for senior citizens and pre-existing illness plans to lure more customers. Health care costs have risen drastically over few years, and any medical treatment can make a dent on individual's savings but with the help of these special health insurance plans, an individual can give extra cushion to them and come out good from these problems. Insurance may be described as a social device to reduce or eliminate the risk of life and property. Under the plan of insurance, a large number of people associate themselves by sharing risk, attached to an individual insurance plan that exclusively covers healthcare costs and is called Health Insurance. One possible solution to the above said problem to reduces the financial barrier through health insurance. Currently only about 10 percent of the population protected under any health insurance coverage. This is for most of employees in the formal (Ellis et al. 2000). The informal workers were unprotected and had to depend on the above poorly financed public sector or the expensive private sector to take care of its needs. The government is keen to increase insurance coverage and has even introduced special health insurance packages for the poor (Times of India, 2003). However, these initiatives have not been acceptable to the citizens of this country (The Economic Times, 2003). Since independence, India struggled to provide its people with universal health coverage but, the majority of Indians remain irregularly and incompletely covered (Forgia and Nagpal, 2012). Health insurance, if properly designed, can decrease the cost and increase the access to quality of health care. Insurance is one of the solutions, as know for every problem there is a solution and here for treatment. Insurance was a form of risk management which primarily hedge against the risk of a contingent, uncertain loss.

\section{Importance of Health Insurance}

Health insurance plays an important role in healthcare services provision. Health insurance is the fast emerging as an important mechanism to finance the health care needs of the people. Health insurance schemes are the one way of guaranteeing access to health care services. Under such schemes, the people should apply for membership and making monthly contributions so that in the event of any sickness; the health insurer will be able to meet the cost of medical care. It should again be noted that the health insurance market depends on policy interventions to balance the supply side and demand side forces. Demand-side forces would naturally involve health insurance participation, and for credible policy interventions, it may be very important for those factors were affecting participation (Mhere, 2013). The need for an insurance system that works on the basic principle of pooling risks of unexpected costs of persons falling ill and needing hospitalization by charging a premium from a wider population base of the community (Bhatia and John, 2000). Workrelated health problems result in an economic loss of four to six percent of gross domestic product for most countries. About 70 percent of workers does not have any insurance to compensate them in occupational disease and injuries. Every health insurance company provides a specialized plan, and sometimes it becomes very difficult to buy an appropriate plan. An individual has to do various analyses and consider factors like coverage and cost into account before buying a health insurance plan. Critical illness policy and pre-existing plans are special plans which can be compared with the help of insurance aggregators as they provide online tools to compare plans offered by different health insurance companies on a single platform. Comparison of various plans in health insurance can help the insurer to buy the best suitable plan as you can compare all aspects (Policy Bazaar, 2016). Buying a critical illness insurance and health insurance plan providing cover for pre-existing illness was not easy. Insurance companies have dedicated plans to cater to this need. Our life is uncertain and we are not aware of the fact of health insurance that any critical illness like heart failure, kidney failure, and stroke can harm us any time and due to rising health care costs and advancement in technology has made these special plans more important. In changing lifestyles and eating habits, these diseases occurrence has seen a visible trend. So, it makes sense to buy health insurance plans covering the critical illnesses 
before they attack us. Insurance for senior citizens can have other special plan that has seen various offerings from the multiple insurance companies. The Insurance Regulatory Development Authority (IRDA) has made it mandatory for insurers to provide insurance for a senior citizen which has benefitted a common man to a large extent. As grow old, more prone diseases can affect and health insurance plan can reduce the financial impact of these diseases. Many health insurance offers a policy of providing health insurance for senior citizens along with critical illness insurance which can reap the benefit an individual has to buy single policy for multiple coverage and method to use finance healthcare. The health insurance programme was the people who have the risk of certain event to contribute a small amount of premium towards a health insurance fund. This fund is used to treat patients who experience that particular event.

\section{Health Insurance in India}

Health care Insurance Awareness in India in 2014 stated that Health insurance is the fast emerging important mechanism to finance the health care needs of the people. The need for an insurance system was that works on the basic principle of pooling of risks of unexpected costs of persons falling ill and needing hospitalization by charging a premium from a wider population base of the same community. The annual expenditure on health insurance in India amounts to about $\$ 7.00$ in rural areas and $\$ 10.00$ in urban areas per person. The majority of insurance care being provided by the private sector, with improved literacy, modest rise in incomes and rapid spread of print and electronic media, the greater awareness and increasing demand for better health services. The growing evidence that the level of health care spending in India currently at over six percent of total Gross Domestic Product considerably higher than that in many other developing countries. This evidence given that more than three-quarters of this spending include private out-of-pocket expenses. The opening up of the health insurance to the private sector by the Insurance Regulatory Development Authority Act 2000 has provided immense opportunities for both the public and the industry for better utilization of health care facilities. At this kind of situation prevailing, there has not much progress in the coverage of population within the health insurance system, only a meager three percent coverage; this was due to lack of awareness on the part of the public determined. Since the past two decades, there was a phenomenal surge in the acceleration of healthcare costs. It compelled that individuals have to re-look on their actual monthly expenditures, spending patterns and simultaneously allocate a proportion of their income towards personal healthcare. This resulted that, individuals availing healthcare insurance coverage not only for themselves but also for their family members. In short, healthcare insurance provides a cushion against medical emergencies. The concept of health insurance closely concerned with the security and acts of shield against risks and unforeseen circumstances. The Indian people were traditionally risk-averse rather than risk lovers by nature. Major health insurance companies in India include National Insurance Company, New India Assurance, United India Insurance, ICICI Lombard, Tata AIG, Royal Sundaram, Star Allied Health Insurance, Cholamandalam DBS, Bajaj Allianz Apollo, AG Health Insurance Company.

The healthcare industry in India comprises hospitals, medicines, infrastructure, medical devices outsourcing telemedicine, health insurance and medical equipment was expected to reach the US \$ 100 billion by 2015 from the current US \$ 65 billion growing around 20 percent a year of the year as per agency and India is traditionally a low spender on health care. India's share in global health expenditure was only four percent of the world's total health expenditure due to that there are many companies trying to support to the Indian healthcare infrastructure. India's health insurance market still lags behind other countries in terms of penetration. Indian Health Insurance sector mainly concentrated towards the urban population and rural population has been neglected since the beginning where nearly 69 percent of Indian Population lives (Sachin and Kumar 2014). The condition of health insurance in India pitiful, as a huge part of our people, does not use health insurance to finance their medical expenditures. As a large majority of people in India believe that health insurance is not a worthy investment and to avoid such health 
insurance products. National Sample Survey Organization investigated that, the main reason for the middle-class people was escalating medical costs. The large proportions of people in India were either avail loans or sell their assets to settle the medical expenditures incurred. The main reason behind this was that in India the people were lack of knowledge of the simple steps to take to secure their healthcare costs. The people are aware of healthcare scenario and the rising costs and often dismiss the need for insurance with the thought that it may be unnecessary. But, India's health care system has gradually improved in the last few decades; it still continues to lag behind its neighboring countries. Indian healthcare expenditure is still low across the globe. The poor state of healthcare in India may be attributed to a lack of government funding on health care initiatives, per capita spending on health care by the Indian government far below the international recommendations (KPMG, 2011 and Pathak, 2011). The country gripped with communicable and noncommunicable diseases, but on the other hand, health care costs are escalating, making access to quality health care were more difficult (National Institutes of Health, 2011 and Pathak, 2011). In India, government hospitals provide a basic care only and often lack adequate infrastructure (Desai, 2009). So, the people prefer to avail private health facilities over public facilities. A hospitalized person in India spends more than half the total expenditure on health care 40 percent of them have to borrow money and sell assets for the payment of health care services and 25 percent of hospitalized fall below the poverty line due to high expenditure on health care (Bhat and Jain, 2006 and James, 2004). India is largely from private out-of-pocket expenditures for financing of health care industry. Most estimates indicated that over 70 percent of the health care expenditures are out of pocket (Desai, 2009 and Nagpal, 2014). Many households were pushed below the poverty line, because of highest out-of-pocket health expenditure (Yojana, 2014).

\section{Objective}

The main objective of the research paper is to discusses the enrolment of health insurance among the informal industrial workers using the Multi- stage Random Sampling Method was adopted. In the first stage, the area of the study was selected in Coimbatore region. In the second stage, the Multispecialty hospitals of cardiac treatment were decided to take as with one Government Hospital and five corporate hospitals Kovai Medical Center and Hospital (KMCH), PSG Hospital, G. Kuppusamy Naidu Memorial Hospital (GKNM), Sri Ramakrishna Hospital, KG Hospital. In the third stage, the Operated Heart Surgery patients were identified. In the fourth stage, the informal industrial workers as in textile, engineering, and foundry informal workers were selected, who were visiting the selected hospitals. The list of workers as cardiovascular disease patient's names, address, and contact number were identified, and the physician was contacted later and permission requested to interview the patients. Most of the interview was taking place in the particular hospital of the cardiac patient visit. After the field survey, the variables related to Enrolment of Health Insurance model were using the Binary Logistic Regression as used for Enrolment, Awareness and Willing to pay for health insurance.

\section{Enrolment of Health Insurance about Gender/ Age/Martial Status/ Nature of Family of Cardiovascular Disease Affected Informal Industrial Workers}

The enrolment of health insurance among the cardiovascular disease affected informal industrial workers in textile, engineering and foundry industry with cross-section to socio-economic background of Gender, Age, Marital Status and nature of Family of workers were depicted in Table 1.The gender wise classification of enrolment of health insurance in textile industry the 163 workers (76.9 percent), engineering 134 workers (72.4 percent) and in foundry 93 workers ( 70.5 percent) was in the male category. In that, 116 workers (74.4 percent) in textile, 68 workers (66.7 percent) were not enrolled in the health insurance, but the male foundry workers were mostly enrolled with 53 workers ( 85.5 percent) in the insurance. The female workers also not enroll category was high in textile 49 workers (25.6 percent), engineering 34 workers (33.3 percent) and in foundry 30 workers (42.9 percent) were not enrolled in the health insurance. 
International Journal of Economics

\section{Table 1: Enrolment of Health Insurance - Gender/Age/Marital Status/ Nature of Family} Cardiovascular Disease Affected Informal Industrial Workers in Coimbatore

\begin{tabular}{|c|c|c|c|c|c|}
\hline \multirow{2}{*}{$\begin{array}{l}\text { Nature of } \\
\text { Industry }\end{array}$} & \multirow{2}{*}{\multicolumn{2}{|c|}{$\begin{array}{c}\text { Gender / Age / Martial Status / } \\
\text { Nature of Family }\end{array}$}} & \multicolumn{3}{|c|}{ Enrolment of Health Insurance } \\
\hline & & & \multirow{2}{*}{$\begin{array}{c}\text { Enrolled } \\
47(28.8) \\
{[83.9]}\end{array}$} & \multirow{2}{*}{$\begin{array}{c}\begin{array}{c}\text { Not } \\
\text { Enrolled }\end{array} \\
116(71.2) \\
{[74.4]}\end{array}$} & \multirow{2}{*}{$\begin{array}{c}\begin{array}{c}\text { Total Industrial } \\
\text { Workers }\end{array} \\
163(100.0) \\
{[76.9]}\end{array}$} \\
\hline \multirow{10}{*}{$\begin{array}{c}\text { Textile } \\
\text { Industrial } \\
\text { Workers }\end{array}$} & \multirow{2}{*}{ Gender } & Male & & & \\
\hline & & Female & $\begin{array}{c}9(18.4) \\
{[16.1]}\end{array}$ & $\begin{array}{c}40(81.6) \\
{[25.6]}\end{array}$ & $\begin{array}{c}49(100.0) \\
{[23.1]}\end{array}$ \\
\hline & \multirow{3}{*}{ Age } & 49 or Less & $\begin{array}{l}22(22.2) \\
{[39.3]}\end{array}$ & $\begin{array}{c}77(77.8) \\
{[49.4]}\end{array}$ & $\begin{array}{c}99(100.0) \\
{[46.7]}\end{array}$ \\
\hline & & $50-59$ years & $\begin{array}{c}29(33.3) \\
{[51.8]}\end{array}$ & $\begin{array}{c}58(66.7) \\
{[37.2]}\end{array}$ & $\begin{array}{c}87(100.0) \\
{[41.0]}\end{array}$ \\
\hline & & 60 and Above & $\begin{array}{c}5(19.2) \\
\quad[8.9]\end{array}$ & $\begin{array}{c}21(80.8) \\
{[13.5]}\end{array}$ & $\begin{array}{c}26(100.0) \\
{[12.3]}\end{array}$ \\
\hline & \multirow{2}{*}{$\begin{array}{l}\text { Marital } \\
\text { Status }\end{array}$} & Married & $\begin{array}{c}52(29.7) \\
{[92.9]}\end{array}$ & $\begin{array}{l}123(70.3) \\
{[78.8]}\end{array}$ & $\begin{array}{l}175(100.0) \\
{[82.5]}\end{array}$ \\
\hline & & $\begin{array}{l}\text { Unmarried/ Widowed/ } \\
\text { Divorced }\end{array}$ & $\begin{array}{c}4(10.8) \\
{[7.1]}\end{array}$ & $\begin{array}{l}33(89.2) \\
{[21.2]}\end{array}$ & $\begin{array}{c}37(100.0) \\
\quad[17.5]\end{array}$ \\
\hline & \multirow{3}{*}{$\begin{array}{l}\text { Nature of } \\
\text { Family }\end{array}$} & Nuclear Family & $\begin{array}{c}52(30.1) \\
{[7.1]}\end{array}$ & $\begin{array}{c}121(69.9) \\
{[77.6]}\end{array}$ & $\begin{array}{l}173(100.0) \\
{[81.6]}\end{array}$ \\
\hline & & Individual & $\begin{array}{c}4(10.3) \\
{[7.1]}\end{array}$ & $\begin{array}{c}35(89.7) \\
{[22.4]}\end{array}$ & $\begin{array}{c}39(100.0) \\
{[18.4]}\end{array}$ \\
\hline & & Total & $\begin{array}{c}56(26.4) \\
{[100.0]}\end{array}$ & $\begin{array}{c}156(73.6) \\
{[100.0]}\end{array}$ & $\begin{array}{c}212(100.0) \\
{[100.0]}\end{array}$ \\
\hline \multirow{9}{*}{$\begin{array}{c}\text { Engineering } \\
\text { Industrial } \\
\text { Workers }\end{array}$} & \multirow{2}{*}{ Gender } & Male & $\begin{array}{c}66(49.3) \\
{[79.5]}\end{array}$ & $\begin{array}{c}68(50.7) \\
{[66.7]}\end{array}$ & $\begin{array}{c}134(100.0) \\
{[72.4]}\end{array}$ \\
\hline & & Female & $\begin{array}{c}17(33.3) \\
{[20.5]} \\
\end{array}$ & $\begin{array}{c}34(66.7) \\
{[33.3]} \\
\end{array}$ & $\begin{array}{c}51(100.0) \\
{[27.6]} \\
\end{array}$ \\
\hline & \multirow{2}{*}{ Age } & $50-59$ years & $\begin{array}{c}43(44.3) \\
{[51.8]}\end{array}$ & $\begin{array}{c}54(55.7) \\
{[52.9]}\end{array}$ & $\begin{array}{c}97(100.0) \\
\quad[52.4]\end{array}$ \\
\hline & & 60 and Above & $\begin{array}{c}15(42.9) \\
{[18.1]}\end{array}$ & $\begin{array}{c}20(57.1) \\
{[19.6]}\end{array}$ & $\begin{array}{c}35(100.0) \\
{[18.9]} \\
\end{array}$ \\
\hline & \multirow{2}{*}{$\begin{array}{l}\text { Marital } \\
\text { Status }\end{array}$} & Married & $\begin{array}{c}74(49.0) \\
{[89.2]} \\
\end{array}$ & $\begin{array}{c}77(51.0) \\
{[75.5]} \\
\end{array}$ & $\begin{array}{c}151(100.0) \\
{[81.6]}\end{array}$ \\
\hline & & $\begin{array}{l}\text { Unmarried/Widowed/ } \\
\text { Divorced }\end{array}$ & $\begin{array}{c}9(26.5) \\
{[10.8]}\end{array}$ & $\begin{array}{c}25(73.5) \\
{[24.5]}\end{array}$ & $\begin{array}{c}34(100.0) \\
{[18.4]}\end{array}$ \\
\hline & \multirow{3}{*}{$\begin{array}{l}\text { Nature of } \\
\text { Family }\end{array}$} & Nuclear Family & $\begin{array}{c}74(46.8) \\
{[89.2]}\end{array}$ & $\begin{array}{c}84(53.2) \\
{[82.4]}\end{array}$ & $\begin{array}{c}158(100.0) \\
{[85.4]}\end{array}$ \\
\hline & & Individual & $\begin{array}{c}9(33.3) \\
{[10.8]}\end{array}$ & $\begin{array}{c}18(66.7) \\
{[17.6]}\end{array}$ & $\begin{array}{c}27(100.0) \\
{[14.6]}\end{array}$ \\
\hline & & Total & $\begin{array}{c}83(44.9) \\
{[100.0]}\end{array}$ & $\begin{array}{c}102(55.1) \\
{[100.0]}\end{array}$ & $\begin{array}{c}185(100.0) \\
{[100.0]}\end{array}$ \\
\hline
\end{tabular}




\begin{tabular}{|c|c|c|c|c|c|}
\hline \multirow{10}{*}{$\begin{array}{l}\text { Foundry } \\
\text { Industrial } \\
\text { Workers }\end{array}$} & \multirow{2}{*}{ Gender } & Male & $\begin{array}{c}53(57.0) \\
{[85.5]}\end{array}$ & $\begin{array}{c}40(43.0) \\
{[57.1]}\end{array}$ & $\begin{array}{c}93(100.0) \\
{[70.5]}\end{array}$ \\
\hline & & Female & $\begin{array}{c}9(23.1) \\
{[14.5]}\end{array}$ & $\begin{array}{c}30(76.9) \\
{[42.9]}\end{array}$ & $\begin{array}{c}39(100.0) \\
{[29.5]}\end{array}$ \\
\hline & \multirow{3}{*}{ Age } & 49 or Less & $\begin{array}{c}18(38.3) \\
{[29.0]}\end{array}$ & $\begin{array}{c}29(61.7) \\
{[41.4]}\end{array}$ & $\begin{array}{c}47(100.0) \\
\quad[35.6]\end{array}$ \\
\hline & & $50-59$ years & $\begin{array}{c}25(46.3) \\
{[40.3]}\end{array}$ & $\begin{array}{c}29(53.7) \\
{[41.4]}\end{array}$ & $\begin{array}{c}54(100.0) \\
{[40.9]}\end{array}$ \\
\hline & & 60 and Above & $\begin{array}{c}19(61.3) \\
{[30.6]}\end{array}$ & $\begin{array}{c}12(38.7) \\
{[17.1]}\end{array}$ & $\begin{array}{c}31(100.0) \\
{[23.5]}\end{array}$ \\
\hline & \multirow{2}{*}{$\begin{array}{l}\text { Marital } \\
\text { Status }\end{array}$} & Married & $\begin{array}{c}58(53.7) \\
{[93.5]}\end{array}$ & $\begin{array}{c}50(46.3) \\
{[71.4]}\end{array}$ & $\begin{array}{c}108(100.0) \\
{[81.8]}\end{array}$ \\
\hline & & $\begin{array}{l}\text { Unmarried/Widowed/ } \\
\text { Divorced }\end{array}$ & $\begin{array}{c}4(16.7) \\
{[6.5]}\end{array}$ & $\begin{array}{c}20(83.3) \\
{[28.6]}\end{array}$ & $\begin{array}{c}24(100.0) \\
{[18.2]}\end{array}$ \\
\hline & \multirow{3}{*}{$\begin{array}{l}\text { Nature of } \\
\text { Family }\end{array}$} & Nuclear Family & $\begin{array}{c}60(53.6) \\
{[96.8]}\end{array}$ & $\begin{array}{c}52(46.4) \\
{[74.3]}\end{array}$ & $\begin{array}{c}112(100.0) \\
{[84.8]}\end{array}$ \\
\hline & & Individual & $\begin{array}{c}2(10.0) \\
{[3.2]}\end{array}$ & $\begin{array}{c}18(90.0) \\
{[25.7]}\end{array}$ & $\begin{array}{c}20(100.0) \\
{[15.2]}\end{array}$ \\
\hline & & Total & $\begin{array}{c}62(47.0) \\
{[100.0]}\end{array}$ & $\begin{array}{c}70(53.0) \\
{[100.0]}\end{array}$ & $\begin{array}{c}132(100.0) \\
{[100.0]}\end{array}$ \\
\hline
\end{tabular}

\section{Source: Primary Data}

The age wise categories of enrolment of health insurance in textile 49 or less age 77 workers (49.4 percent) were not mostly enrolled in the health insurance and 51-59 years of age were highly enrolled with 29 workers (51.8 percent). But in engineering and foundry, most of the workers in the age group of 50-59 years as 54 workers (52.9 percent) and 29 workers (41.4 per cent) were not enrolled. From the data, identified that the workers above 60 years and above enrolled category was very low, if they are willing to enroll in the health insurance due to the age factor they are can't able to get benefits of health insurance. The researcher identified, the enrolment of workers in the age group of 60 years and the above were enrolled the health insurance at the age of their 40 years and above.

Comparing with the married and unmarried/ widowed/divorced category on enrolment of health insurance, the nonenrolment of married workers health insurance was high. In this, the textile industrial workers those who married were not enrolled in health insurance as 123 workers (78.8 percent), in engineering 77 workers (75.5 percent) but in foundry more married workers were get enrolled in the health insurance with 93.5 percent (58 workers). In the unmarried/widowed/divorced category also the enrolment of health insurance as low as in textile only four workers (7.1 percent), engineering nine workers (10.8 percent) in foundry four workers (6.5 percent) were having health insurance. The researcher identified that most of the married workers were got their health insurance not only for them but also to the whole family.

The nature of the family mostly belongs to the nuclear family, category enrolment of health insurance was very low. In textile nuclear family enrolment was only 52 workers (29.7 percent) but not enrolled were 121 workers (69.9 percent) as that 77.6 per cent of workers in the nuclear family not get enrolled in insurance. In the engineering 84 workers (82.4 percent) and foundry 52 workers ( 74.3 percent) were not enrolled in health insurance. The workers those who are living individual also enrolled their insurance but at very low percent. The researcher identified that the workers in the male category at the age of 50-59 years and those who are married and come under a nuclear system of the family mostly enrolled in the health insurance.

\section{Binary Logistic Regression Analysis - Enrolment of Health Insurance of Cardiovascular Disease affected Informal Industrial Workers}

To examine the research question, the researcher used the binary logistic regression was conducted 
to assess the independent variable(s) to predict the dependent variable. The binary logistic regression was an appropriate statistical analysis when the purpose of research to assess if a set of independent variables predicted a dichotomous dependent variable (Stevens, 2009). This type of analysis can be used when the independent variables (predictors) are continuous, discrete, or a combination of continuous and discrete. For this research question, the independent variables are independent variable 1 , independent variable 2, and the like, the dependent variable and consist of two levels. This analysis permitted that evaluation of the odds of membership in one of the two outcome groups based on the combination of predictor variable values. The overall model significance for the binary logistic regression was examined using the $\chi^{2}$ omnibus test of model coefficients. The Nagelkerke R2 was examined to assess the percent of variance accounted for the independent variables, predicted probabilities of an event occurring determined by $\operatorname{Exp}(\beta)$.

In this section, an attempt was made to examine the determinants of risk factor 2 in causing cardiovascular disease among informal industrial workers. For this purpose, the risk factors that cause cardiovascular disease has been considered as a dependent variable, which was measure into two categories viz., respondents who felt to be affected risk factors such as Cholesterol, Diabetes, Alcohol Consumption and Heredity (coined as Risk Factor 2, which was assigned a score of ' 1 ') and those who felt to be affected by risk factors like Hypertension, Stress, Smoking and Age (named as Risk Factor 1, which was assigned a score of ' 0 '). All the selected independent variables included in the model based on theoretical importance and levels of significance with Risk Factors $1 \& 2$ in the cross-tabular analysis are categorized in nature. In such a condition, the application of the binary logistic regression analysis was apter.

Nketiah (2009) used a binary logit model and established that variables in determining participation are income, age, religion, access to health information via television sets and the media, and some variables are significant predictors for women's participation. To find out the determinants of industrial workers those who affected by the cardiovascular disease were enrolment in any health insurance scheme, in this section, an attempt was made to make use of binary logistic regression. For this purpose, the workers enrolment of health insurance was considered as dependent variable, based on which all the respondents have categorized into two groups viz., respondents who enrolled themselves in any health insurance scheme (a score of ' 1 ' is assigned) and those who don't enroll themselves in any such scheme (a score of ' 0 ' is given). All the selected independent variables included in the model are chosen based on their theoretical importance and levels of significance with the enrolment of health insurance in the cross-tabular analysis.

Table 2: Results of Binary Logistic Regression Analysis on Enrolment of Health Insurance of Cardiovascular Disease affected Informal Industrial Workers

\begin{tabular}{|l|c|c|c|}
\hline \multicolumn{1}{|c|}{ Explanatory Variables } & B Co efficient & Odds Ratio & p-value \\
\hline Age (Ref: $\leq$ 49Years) & ---- & 1.000 & -- \\
50 - 59 Years & 0.329 & 1.390 & 0.140 \\
60 Years and above & 0.030 & 1.031 & 0.919 \\
\hline Gender (Ref: Males) & -- & 1.000 & -- \\
Females & -0.876 & 0.416 & 0.001 \\
\hline Nativity (Ref: Rural) & -- & 1.000 & -- \\
Urban & -0.361 & 0.697 & 0.154 \\
\hline Marital Status (Ref: UM / WI / DI) & -- & 1.000 & -- \\
Married & 0.796 & 2.256 & 0.01 \\
\hline Educational Qualification & & & -- \\
(Ref: Illiterates \& Primary School) & -- & 1.000 & 0.386 \\
Middle and Secondary School & -0.198 & 0.820 & 0.867 \\
Higher Secondary School and above & -0.052 & 0.949 & \\
\hline
\end{tabular}




\begin{tabular}{|c|c|c|c|}
\hline $\begin{array}{l}\text { Type of Industry (Ref: Textile) } \\
\text { Engineering } \\
\text { Foundry }\end{array}$ & $\begin{array}{l}-- \\
0.903 \\
1.053\end{array}$ & $\begin{array}{l}1.000 \\
2.467 \\
2.865\end{array}$ & $\begin{array}{l}-- \\
0.001 \\
0.001\end{array}$ \\
\hline $\begin{array}{l}\text { Monthly Income of the Family (in Rs.) } \\
\text { (Ref: } \leq 12000) \\
12001-24000 \\
24001 \text { and above }\end{array}$ & $\begin{array}{l}-- \\
0.462 \\
0.987\end{array}$ & $\begin{array}{l}1.000 \\
1.587 \\
2.684\end{array}$ & $\begin{array}{c}-- \\
0.05 \\
0.001\end{array}$ \\
\hline $\begin{array}{l}\text { Health Status (Ref: Very Poor) } \\
\text { Poor } \\
\text { Average \& Good }\end{array}$ & $\begin{array}{c}-- \\
-0.422 \\
-0.101\end{array}$ & $\begin{array}{l}1.000 \\
0.655 \\
0.904\end{array}$ & $\begin{array}{l}-- \\
0.153 \\
0.726\end{array}$ \\
\hline $\begin{array}{l}\text { - } 2 \text { Log likelihood } \\
\text { Chi-square (d.f.) } \\
\text { Significance Level } \\
\text { N } \\
\text { Cox \& Snell R Square } \\
\text { Nagelkerke R Square }\end{array}$ & & $\begin{array}{c}628.335 \\
74.226(13) \\
0.001 \\
529 \\
13.1 \\
17.8\end{array}$ & \\
\hline
\end{tabular}

Results from the binary logistic regression analysis (Table 2) showed that, among the sample informal industrial workers, as a whole, 4 out of 8 explanatory variables (or their categories) under consideration have exhibited statistically significant net effects on their enrolment in any health insurance scheme. Controlling all the variables used in the model, it was striking to note that the odds of informal industrial workers enrolment of any health insurance scheme are about 2.87 times and 2.47 times higher among those who are working in foundry industry and engineering industry, respectively than among who are working in the textile industry. Moreover, the concerned t-test results are also emerged as highly significant $(\mathrm{p}<0.001)$ in each case. Next to this, it was also conspicuous to note that such odds are 2.68 times and 1.59 times higher among those who belonged to most and moderate monthly family income brackets (Rs. 24,001 \& above and Rs. 12,001-24,000) than those who are from lower family income category (Rs. 12,000 or less). However, the t-test results have turned out as highly significant in the case of higher income bracket and moderately significant in the case of middle family income bracket $(p<0.001$ and $\mathrm{p}<0.05$, respectively) Some studies related were by Platteau and Oativeroa (2013), Gustafsson Wright et al (2009), Yamada et al, (2009).

Among the other factors, the role of marital status and gender on their enrolment into any health insurance was worth noting. For instance, it was prominent to note that the odds of industrial workers enrolment in any health insurance scheme were significantly higher among those who are currently married $(\mathrm{OR}=2.26 ; \mathrm{p}<0.01)$ as compared to their female counterparts. On the other hand, it striking to note that the likelihood of enrolling themselves in any health insurance scheme was lower among the females as against their male counterparts (OR $=0.42$ ) and the t-test results in this regard are also turned out as highly significant $(\mathrm{p}<0.001)$. Some of the following factors have exhibited differential direction of net effects on their enrolment in any health insurance scheme, but statistically insignificant manner. Of these, it was conspicuous to note that the likelihood of enrolment in health insurance scheme it was higher among those who belonged to higher age categories under consideration (50-59 and 60 years $\&$ above; OR $=1.39$ and 1.03 , respectively) than those younger (49 years or below). Conversely, such likelihood was lower among those whose nativity was urban areas $(\mathrm{OR}=0.70)$, educated up to middle and secondary school levels as well as higher secondary school level (OR $=0.82$ and 0.95 , respectively). These findings are contrary to the expectation, the reason was the disease affected workers were getting covered by the insurer in the rural areas, and those in the age of above 50 were highly covered in the study. Among those who reported their health status as average and good as well as poor $(\mathrm{OR}=$ 0.66 and 0.90 , respectively) as compared to their respective counterparts. The reasons for the health status of cardiovascular disease affected informal industrial workers were poor because of the work in the industry and that they were preferring for 
health insurance. The evidence of studies as given by Polsky et al. (2005), Wanjiku (2011), Asuming (2013), Kramer (2016), Kansra and Gill (2017).

\section{Concluding Observation}

Many countries today are shifting over to health insurance as a mechanism of financing their healthcare programme. In India, the people need to shift from the current predominance of out-of-pocket payments to a health insurance programme. The reasons are clear:

- Direct out-of-pocket payments are a financial barrier to accessing health services. The insured patient can walk into a healthy facility without the fear of financial burden in hospital;

- Direct out-of-pocket payments can push the families into indebtedness and poverty. Health insurance can protect the patients from burden of raising funds at the time of their illness;

- Direct out-of-pocket payments are inequitable as they can place the burden on the vulnerable. Risk pooling mechanism was more equitable in health insurance and

- Direct out-of-pocket payments do not permit the patient's participation in his/her treatment. In a collective nature, the health insurance programme can negotiate by people with better quality care.

India has achieved a lot in terms of health improvement during the last 50 years. India was way behind many fast-developing countries such as China, Vietnam and Sri Lanka in health indicators. The government-funded health care system, the quality and access of services have always remained major concern. India is growing rapidly in private health market has developed. This private sector bridges most of the gaps between what the government offer and what people need? However, with the proliferation of various health care technologies and general price rise, the cost of care has also become very expensive and unaffordable to a large segment of the population. The government and the people have started exploring various health financing options to manage problems arising out of growing set of complexities of private sector growth, increasing the cost of care and changing the epidemiological pattern of diseases. The proportion of insurance in health care financing in India was low. Health care financing in India as Public spending in health care was very low at 17 percent and the National Health Policy has recognized this more than 86 percent of healthcare financing through unplanned or, noncontributory spending 86 percent from out of pocket expenses 83 percent from private sector spending. The main reason, was there has been restraint in the growth of Health Insurance, during the last decade as inadequate healthcare infrastructure, Limited reach, Significant underwriting losses for Health Insurance business in India, Lack of standardization and Accreditation norms in healthcare industry in India, Insufficient data on Indian consumers and disease patterns resulting in difficulty in product development and pricing.

\section{References}

Akazili J., "Equity in Healthcare Financing in Ghana," Doctoral Thesis, Health Economics Unit, Cape Town University, Cape Town, South Africa. 2010.

Bhatia J.C \& John C., "Health care Seeking and Expenditure by Young Mothers in Public and Private Sectors," Health Policy and Planning, Vol 16 (1), 2000, pp. 55-61.

Chatterjee C, Joshi R \& Sood N., "Health Insurance and Its Role in Spatially Diffusing Information: New Evidence from the Indian state of Karnataka," pp. 1-31. 2013.

Desai S., "Keeping the Health in Health Insurance," Economic and Political Weekly, Vol. 44(38), 2009, pp.no.18-21.

Devadasan N., "Planning and Implementing Health Insurance Programmes in India: An Operational Guide," Institute of Public Health, Bangalore, India, 2005.

Kahn A.M.J., "Impact of Education on Informal Workers Willingness to pay and Knowledge of Health Insurance," Research Paper, 2012, No.16.

KPMG "Emerging Trends in Healthcare - A Journey from Bench to Bedside," Association of Chamber of Commerce and Industry, New Delhi, India, 2011.

Kramer B., "From Awareness of Adverse Selection: Cardiovascular Disease Risk and Health 
Insurance Decisions," WIDER Development Conference, Human Capital and Growth, Helsinki, Finland. 2016.

Pathak B., "The Indian Financial System" Pearson, New Delhi, 2011.

Yamada T, Chen C, Yamada T, Noguchi H \& Miller M., "Private Health Insurance and Hospitalization Under Japanese National
Health Insurance," The Open Economics, pp.no.61-70. 2009.

Yojana "Non-communicable Diseases and Development in India," Yojana - A Development Monthly, 2(2), 2014, pp.no.62.

\section{Author Details}

Dr.R.Naagarajan, Associate Professor and Head, Department of Economics, PSG College of Arts and Science, Coimbatore, Tamil Nadu, India

K.Jayavasuki, Ph.D. Research Scholar, Department of Economics, PSG College of Arts and Science, Coimbatore, Tamil Nadu, India 